\title{
Clinical and Immunologic Characteristics of Healthy Children with Subnormal Serum Concentrations of IgG2 ${ }^{1}$
}

\author{
PENELOPE G. SHACKELFORD, DAN M. GRANOFF, JOSEPH V. MADASSERY, MITCHELL G. SCOTT, \\ AND MOON H. NAHM \\ Division of Infectious Diseases, Edward Mallinckrodt Department of Pediatrics [P.G.S., D.M.G.], and the \\ Division of Laboratory Medicine, Department of Pathology [J.V.M., M.G.S., M.H.N.], Washington University \\ School of Medicine. St. Louis, Missouri 63110
}

\begin{abstract}
To understand the relevance of subnormal serum concentrations of IgG2, we measured IgG2 in serum of 575 healthy children and identified 11 with concentrations $>2$ SD less than the mean for age. The levels of IgG2 present were similar to those found in symptomatic children with IgG2 subclass deficiency associated with antibody deficiency. The 11 children ranged in age from 1 to $14 \mathrm{y}($ mean $=5.7)$. Detailed clinical information was available on 10 of the 11 children and each was matched for age with two controls. The median number of visits/y to the doctor for infectious illnesses was identical for the two groups (1.0). Nine of the children with subnormal IgG2 were followed for 1 to $5 \mathrm{y}$ (mean = 2.3). All nine children had normal serum concentrations of IgA, IgG1, IgG3, and IgG4 but seven had persistently subnormal or low-normal serum IgG2 concentrations. One of these seven children also had a subnormal serum concentration of IgG, and one had subnormal IgM. Antibody responses to Haemophilus b polysaccharide vaccine were normal in five of six who were immunized. In vitro secretion of Ig by mitogen-stimulated peripheral blood mononuclear cells was measured in six of seven children with persistently subnormal or lownormal IgG2; five showed decreased secretion of IgG2, and two of the five also had subnormal secretion of IgG1 and IgG3. An important implication of this study is that the subnormal concentrations of serum IgG2 found in infectionprone children are not a sufficient explanation for their increased susceptibility to infection. The healthy children with low serum concentrations of IgG2 differ from symptomatic children with subnormal IgG2 in that the former have otherwise normal serum Ig concentrations and have normal antibody responses to Hib PS vaccine. (Pediatr Res 27: 16-21, 1990)
\end{abstract}

\section{Abbreviations}

Hib PS, Haemophilus influenzae type b capsular polysaccharide

Hib PS-D, Haemophilus b diphtheria toxid conjugate PBL, peripheral blood mononuclear cells

\footnotetext{
Received May, 18, 1989; accepted August 29, 1989.
}

Reprint requests Dr. Penelope Shackelford, Department of Pediatrics, Washington University School of Medicine, Division of Infectious Diseases, Children's Hospital, 400 South Kingshighway, St. Louis, MO 63110.

${ }^{1}$ Presented in part at the Annual Meeting of the Society for Pediatric Research, Washington, DC, May, 1989.

Supported by Grants R01 AI19350, AIl 7962 and AI19676 from the National Institute of Allergy and Infectious Diseases, and Grant RR-36 from the General Clinical Research Center Branch, National Institutes of Health. Flow cytometry was supported by AI 15353 .
The relation between the IgG2 subclass of human Ig and protective immunity against infectious diseases is incompletely understood. The observation that antibodies produced in response to some polysaccharide antigens are often relatively restricted to $\operatorname{IgG} 2(1,2)$ has suggested a special role for $\operatorname{IgG} 2$ in protective immunity to infections caused by polysaccharide encapsulated organisms. For example, a relationship between the slow maturation of serum IgG2 concentrations and the poor antibody responses of normal children to polysaccharide antigens has been suggested (3-5). Further, many reports have described children and adults with subnormal serum concentrations of IgG2 who experience recurrent sinusitis, pneumonia, and/or bacteremic infections caused by polysaccharide encapsulated bacteria (6-11). However, skepticism regarding a simple relationship between serum IgG2 concentrations and protective immunity has arisen following reports of several healthy subjects with no detectable serum $\operatorname{IgG} 2$ who have a deletion of the constant region gene for $\operatorname{IgG} 2(12,13)$.

To understand better the clinical relevance of subnormal serum concentrations of IgG2 in children, we identified a group of children in primary care facilities with serum IgG2 concentrations more than 2 SD less than the mean for age. We present the results of a detailed review of the clinical histories of these children and the results of a prospective study of their serum Ig concentrations, antibody response to Hib PS, and in vitro secretion of IgG subclasses after mitogen stimulation.

\section{MATERIALS AND METHODS}

Subjects. After obtaining informed, written consent from parents, serum samples for measurement of $\mathrm{IgG} 2$ were obtained from 575 healthy children, ages 7 to $203 \mathrm{mo}$, at the time of visiting their pediatrician at a prepaid health care group program for well-child care, or when admitted for elective surgery to St. Louis Children's Hospital. Surgical patients were undergoing orthopedic procedures, hernia repair, or eye muscle surgery. Children were excluded if they had multiple anomalies or a history of frequent infections (children with myringotomy tubes, or more than six physician visits annually for infection). Of the 575 samples, 483 were from venous blood, and were used to establish the normal ranges of IgG2. Of these, $10(2.1 \%)$ had subnormal serum IgG2 concentrations ( $>2$ SD less than mean for age) (Table 1). The median age and dispersion of ages of the children with subnormal IgG2 did not differ from those of children with normal $\mathrm{IgG} 2$ concentrations. Inasmuch as results of assays for IgG2 gave 10-20\% lower values on capillary compared to venous samples (Shackelford PG, unpublished data), results of measurement of $\mathrm{IgG} 2$ in capillary samples were not used to establish the normal ranges. However, we used capillary samples to identify additional healthy children younger than 18 
mo of age with subnormal IgG2. Among 92 children screened using capillary samples, one was found to have subnormal serum IgG2 that was subsequently confirmed on venous blood. Thus, during the study period between September 1985 and March 1987, 11 apparently healthy children with subnormal serum IgG2 concentrations were identified. Parents of nine of the children consented to further immunologic evaluation and these children have been followed through May 1988.

Clinical History. Detailed clinical histories were obtained on 10 of the 11 children with subnormal serum IgG2 concentrations and also for two age-matched controls from the same pediatrician's practice. Criteria for inclusion of the controls were identical to those used for children with subnormal IgG2. For each child, both the medical records were examined and a parent was interviewed. Comparisons were made of the number of visits to the pediatrician for infectious illnesses during the 12-mo intervals before the initial serum sample, and before the last available sample. Reasons for visits to the pediatrician were categorized as upper respiratory infection (including pharyngitis), otitis media, gastroenteritis, sinusitis, lower respiratory infection, and "other".

Vaccine Response. Children were immunized subcutaneously with $25 \mu \mathrm{g}$ of Hib PS prepared by Praxis Biologics (Rochester, NY). Postimmunization serum was obtained 1 to 3 mo after immunization. Normal values for serum antibody concentrations after immunization were based on previously published values (14), and on contemporaneous study of 36 healthy children vaccinated with Hib PS. These 36 children ranged in age from 2.0 to 12.4 y (mean $=3.5$ ), and had normal serum $\operatorname{IgG} 2$ concentrations. Their antibody responses were indistinguishable from the previously published values and therefore the data were combined.

Assays. Ig. Serum IgG, IgA, and IgM were measured by nephelometry (Beckman Instruments, Fullerton, CA). Serum concentrations of $\mathrm{IgG} 1, \mathrm{IgG} 2, \mathrm{IgG} 3$, and $\mathrm{IgG} 4$ were measured using murine $\mathrm{MAb}$ and a particle concentration fluorescence immunoassay as previously described (15). The IgG1-specific murine MAb (HG11) was produced in our laboratory (16). The IgG2-specific antibody (HP6008, GOM1) was purchased from ICN Immunobiologicals, Lisle, IL. G2m(23)-positive and $\mathrm{G} 2 \mathrm{~m}(23)$-negative myeloma proteins are detected equally by this antibody (15). The IgG3-specific antibody (HP6066) was obtained from Dr. M. E. Conley (Philadelphia, PA). An IgG4specific antibody, HP6011, was purchased from Unipath Limited, Bedford, U.K. As previously described (15), the subclass assays are highly specific and sensitive. The interassay coefficient of variation ranged from 7 to $14 \%$. However, to assess changes in a serum IgG subclass concentration in a subject over time, all samples from an individual were rerun in the same assay.

Table 1. $\operatorname{IgG}_{2}$ subclass concentrations in children without history of increased infections

\begin{tabular}{ccccc}
\hline & No. & $\begin{array}{c}\text { Geometric } \\
\text { mean }\end{array}$ & & $\begin{array}{c}\text { No. with } \mathrm{IgG}_{2} \\
\text { >2 SD } \\
\text { less than }\end{array}$ \\
Age (mo) & $\begin{array}{c}\text { tested } \\
(\mathrm{mg} / \mathrm{mL})\end{array}$ & Normal bounds* geometric mean \\
\hline $7-11$ & 25 & 0.38 & $0.13-1.09$ & $0 \dagger$ \\
$12-23$ & 47 & 0.76 & $0.26-2.19$ & 1 \\
$24-35$ & 47 & 0.99 & $0.42-2.31$ & 1 \\
$36-59$ & 80 & 1.11 & $0.37-3.34$ & 3 \\
$60-83$ & 85 & 1.29 & $0.43-3.89$ & 1 \\
$84-107$ & 56 & 1.51 & $0.52-4.42$ & 2 \\
$108-131$ & 50 & 1.81 & $0.66-4.96$ & 1 \\
$132-203$ & 93 & 2.35 & $0.83-6.62$ & 1 \\
\hline
\end{tabular}

* Normal bounds were determined by taking antilog of (mean logarithm \pm 2 SD of logarithms).

† One subject was identified in this age group from the 92 subjects $<18$ mo screened by measurement of $\mathrm{IgG}_{2}$ in capillary blood. The low concentration of $\mathrm{IgG}_{2}$ in the capillary sample was confirmed in a subsequent sample from venous blood (see text).
To assess the stability of serum IgG2 levels in normal children, we measured under code IgG2 concentrations in paired sera obtained 1 to 2 mo apart from 19 children with a mean age of $3.02 \mathrm{y}$. The mean \pm SD of the difference in the paired values was $4.3 \pm 14 \%$. The direction of variation was random; values decreased in 12 children and increased in seven.

$G 2 m(23)$ allotype assay. G2m(23) allotype was determined with an assay method similar to the $\operatorname{IgG} 2$ assay. Latex particles coated with a G2m(23)-positive myeloma protein, SAG2 (kindly provided by Dr. Robert Kyle, Rochester, MN), were incubated with SH21 (ICN Immunobiologicals, Lisle, IL), a murine MAb specific for the G2m(23)-positive allotype, and an appropriately diluted serum sample. $\mathrm{G} 2 \mathrm{~m}(23)$ protein in the sample inhibits binding of SH21. The amount of SH21 bound to latex particles was determined with fluorescein-conjugated goat antibody to mouse Ig. The $\mathrm{G} 2 \mathrm{~m}(23)$ assay was initially standardized with purified SAG2 protein that gave a value of $1.8 \mathrm{~g} / \mathrm{L}$ of $\mathrm{G} 2 \mathrm{~m}(23)$ positive IgG2 for a pool of human serum from 1638 blood donors. This pool was subsequently used as the standard for all $\mathrm{G} 2 \mathrm{~m}(23)$ assays. The ratio of concentrations of $\mathrm{G} 2 \mathrm{~m}(23)$-positive $\operatorname{IgG} 2$ to total IgG2 in a sample was used to determine its $\mathrm{G} 2 \mathrm{~m}(23)$ allotype. All samples with a $\mathrm{G} 2 \mathrm{~m}(23)$-positive/ $\mathrm{IgG} 2$ ratio less than 0.2 were called $G 2 \mathrm{~m}(23)$ negative, and samples with a ratio more than 0.2 were called $\mathrm{G} 2 \mathrm{~m}(23)$ positive. Of $141 \mathrm{G} 2 \mathrm{~m}(23)$ positive samples, the $\mathrm{G} 2 \mathrm{~m}(23) / \mathrm{IgG} 2$ ratio was $0.62 \pm 0.19$ (mean $\pm \mathrm{SD}$ ) and the range was 0.29 to 1.18 . Samples negative for the allotype were always less than the sensitivity of the assay $(0.1 \mathrm{~g} /$ L) and, thus, usually had ratios far less than 0.2 .

Antibody assays. Total antibody to Hib PS was measured using a radioactive antigen binding assay with ${ }^{125}$ I-labeled antigen (17). The antibody concentrations, in $\mu \mathrm{g} / \mathrm{mL}$, were determined from a standard curve using dilutions of the U.S. Office of Biologics serum reference pool estimated to contain $80 \mu \mathrm{g} / \mathrm{mL}$ of total antibody in undiluted serum.

ELISA were used to measure $\mathrm{IgG1}$ and $\mathrm{IgG} 2$ antibodies to $\mathrm{Hib}$ PS. IgG3 , and IgG4 antibody concentrations were not measured because in most individuals they represent only a minor component of anti-Hib PS antibodies (18). For measurement of IgG1 and $\mathrm{IgG} 2$ antibody concentrations, microtiter plates were coated with polysaccharides conjugated to poly-L-lysine, test sera were titrated in the plate, and binding of subclass-specific antibody was detected with biotinylated conjugates of secondary antibodies as previously described (19). The anti-IgG1 reagent was MAb HG11 (16). To detect IgG2 antibodies, a mixture of two MAb was used (HP6014 and HP6008 from ICN, Immunobiologics, Lisle, IL) to achieve optimal sensitivity whereas minimizing the light chain preference of HP6014 (15).

Enumeration of leukocyte populations. PBL isolated by Ficoll separation were stained and enumerated by flow cytometry as described (20). To enumerate subpopulations among lymphocytes, nonlymphocytes were "gated out" using forward and $90^{\circ}$ scatter signals. We used MAb Leu 4, Leu 3, Leu 2, Leu $11 \mathrm{~b}$ and $\mathrm{B} 1$ for $\mathrm{CD} 3, \mathrm{CD} 4, \mathrm{CD} 8, \mathrm{CD} 16$, and CD20 antigens, respectively.

In vitro subclass secretion. In vitro secretion of IgG subclasses by isolated human PBL was performed as previously described (16). In brief, cells were recovered from $20 \mathrm{~mL}$ of heparinized blood using Ficoll-Hypaque and Percoll sedimentation, washed, and cultured in 48-well cluster plates (Costar Plastics, Cambridge, MA). The $0.8 \times 10^{6}$ cells were cultured for $8 \mathrm{~d}$ in $0.75 \mathrm{~mL}$ of RPMI 1640 (GIBCO, Grand Island, NY) supplemented with endotoxin-free heat-inactivated FCS (GIBCO) (final concentration $10 \%), 100 \mu \mathrm{g} / \mathrm{mL}$ of streptomycin, $100 \mu \mathrm{g} / \mathrm{mL}$ of penicillin, $2 \mathrm{mM}$ L-glutamine, and $1 \%$ tryptic soy broth (Difco Laboratories, Detroit, MI). For stimulation, each well contained staphylococcal protein A $(0.005 \%)$ and pokeweed mitogen $(0.033 \%)$. The mitogen doses chosen induced optimal secretion of the $\mathrm{IgG}$ subclasses (16).

ELISA were used to measure concentrations of $\operatorname{IgG} 1, \operatorname{IgG} 2$, and IgG3 in the supernates. Dynatech Immulon plates (Chantilly, VA) were coated with $10 \mu \mathrm{g} / \mathrm{mL}(120 \mu \mathrm{L})$ of MAb specific for either IgG1 (HG11), IgG2 (HP6016), or IgG3 (HP6066). 
Uncoated sites were blocked with $1 \%$ BSA diluted in PBS and $0.5 \%$ Tween 20 . Appropriately diluted culture supernates were added and titrated in serial 4-fold dilutions and incubated at room temperature for $3 \mathrm{~h}$. After washing, bound IgG subclasses were detected with an alkaline phosphatase-conjugated goat antihuman IgG and p-nitrophenylphosphate as the substrate. IgG subclass concentrations in the unknown samples were calculated by comparison of the absorbance of the unknown with that of a set of myeloma proteins and dilutions of a standard serum pool.

Statistical Analysis. The normal bounds for IgG2 in various age groups were determined by taking the antilog of (mean logarithm $\pm 2 \mathrm{SD}$ of the logarithms). At least 25 subjects were included in each age group. A Mann-Whitney test was used to compare frequency of visits for infectious illnesses.

\section{RESULTS}

Clinical history. Of the 11 healthy children with subnormal serum IgG2 concentrations, we were able to contact 10 to obtain detailed clinical information and were able to follow them over a period of 1.0 to 5.1 y (mean $=2.3$ ). One child, age $14.1 \mathrm{y}$ (subject 4), had a history of pneumococcal meningitis at age 3 mo and four episodes of pneumonia treated as an outpatient, before the age of $5 \mathrm{y}$. However, this child is included because he had been free of serious or frequent infections for the following $9 \mathrm{y}$. None of the other nine children had a history of serious infections, and they did not visit their physician more frequently for infectious illnesses during the $12 \mathrm{mo}$ preceding the initial serum sample than did the 20 age-matched control subjects (median number of visits for infectious illnesses $=1.0 / \mathrm{y}$ for both groups). During follow-up, the children with subnormal IgG2 concentrations remained clinically healthy, and during the last year of follow-up they did not visit their physicians more frequently than the age-matched healthy control children ( 1.5 visits/ $\mathrm{y}$ versus 2.0 visits $/ \mathrm{y}, \mathrm{p}>0.05)$.

$\mathrm{G} 2 \mathrm{~m}(23)$ allotype. $\mathrm{G} 2 \mathrm{~m}(23)$ is an allotype on $\mathrm{IgG} 2$ molecules found predominantly in Caucasians (21). The frequency of this allotype in Caucasians is approximately $57-76 \%(17,22)$. In previous studies, Caucasian adults who were negative for $\mathrm{G} 2 \mathrm{~m}(23)$ had lower serum IgG2 concentrations than those who were $\mathrm{G} 2 \mathrm{~m}(23)$ positive $(3,23)$. In a recent study of 8015 blood donors, 14 of the 15 individuals with $\operatorname{IgG} 2$ concentrations $3 \mathrm{SD}$ less than the mean were $\mathrm{G} 2 \mathrm{~m}(23)$ negative (expected approximately 6), $p<0.01$ by Fisher Exact test (Nahm MH, unpublished data). G2m(23) was determined in sera from 10 of the 11 children (Table 2) and was present in four of the eight Caucasian children tested (expected approximately three). Thus, in the children, this frequency is not significantly different from that expected in healthy Caucasian subjects.

$I g$. Sufficient sera were available from the initial screening samples to determine serum IgG, IgA, and IgM concentrations in eight of the 11 children, and $\operatorname{lgG} 1, \operatorname{IgG} 3$, and $\operatorname{lgG} 4$ in nine of the children (Table 2). Three of the children had abnormal values: one child (subject 7) had subnormal concentrations of IgG and, possibly, IgA, one child (subject 1) had subnormal concentrations of $\operatorname{IgG} 1$ and $\operatorname{IgG} 4$, and one child (subject 6) had a subnormal $\mathrm{IgG} 1$ concentration.

The parents of nine of the 11 children consented to have follow-up immunologic evaluation of their child. These evaluations were performed at a median interval of $1.9 \mathrm{y}$ after obtaining the initial serum sample (range 1.0 to $5.1 \mathrm{y}$ ). As shown in Figure 1 and Table 3, five of the nine children had persistently subnormal IgG2 concentrations at the time of follow-up. Of the remaining four children, two had low-normal $\mathrm{IgG} 2$ values and two had normal $\mathrm{IgG} 2$ concentrations. One of the children with a lownormal IgG2 value (subject 4) also had a subnormal IgG concentration, and one with a subnormal IgG2 value (subject 7) had subnormal IgM, but all nine had normal serum concentrations of IgA, IgG1, IgG3, and IgG4 (Table 3).

Response to Hib PS vaccine. Six of the nine children were immunized subcutaneously with $25 \mu \mathrm{g}$ conventional Hib PS vaccine prepared by Praxis Biologics (Rochester, NY) (Table 3). One additional child (subject 4) was inadvertently immunized intramuscularly with $0.5 \mathrm{~mL}$ of Hib PS-D vaccine (Connaught, Swiftwater, PA) containing $25 \mu \mathrm{g}$ of capsular polysaccharide (24). The two unimmunized children (subjects 2 and 9) had prevaccine serum antibody concentrations of 0.7 and $1.2 \mu \mathrm{g} / \mathrm{mL}$, concentrations within the normal range for children of this age (14). At the time of immunization, all six of the children who received polysaccharide vaccine had subnormal serum concentrations of IgG2; the seventh child, who received conjugate (subject 4, Table 3 ), had low-normal serum IgG2 when he was immunized. Six of the seven immunized children had normal total anti-Hib PS responses to immunization. Of these, four had detectable IgG1 responses $(>0.5 \mu \mathrm{g} / \mathrm{mL})$ and three had detectable $\mathrm{IgG} 2$ responses $(>0.3 \mu \mathrm{g} / \mathrm{mL})$ (Table 3). This pattern of IgG subclass responses is similar to that observed previously in children immunized with either Hib PS or Hib PS-protein conjugate vaccines (25). Only one of the immunized children (subject 7) had a subnormal

Table 2. Initial immunologic and clinical features of apparently healthy children with low IgG2 concentrations

\begin{tabular}{|c|c|c|c|c|c|c|c|c|c|c|c|}
\hline \multirow[b]{2}{*}{ Subject } & \multirow[b]{2}{*}{ Age $(y)$} & \multirow[b]{2}{*}{ Race* } & \multirow[b]{2}{*}{$\mathrm{Gm}(23)$} & \multirow[b]{2}{*}{ Visit/y† } & \multicolumn{7}{|c|}{ Ig concentrations (mg/mL) } \\
\hline & & & & & $\mathrm{G}_{1}$ & $\mathrm{G}_{2}$ & $\mathrm{G}_{3}$ & $\mathrm{G}_{4}$ & G & $\mathrm{A}$ & $\mathrm{M}$ \\
\hline 1 & 4.6 & $\mathrm{~B}$ & - & 1 & $1.78 \ddagger$ & $0.32 \ddagger$ & 0.17 & $0.007 \ddagger$ & $\mathrm{ND} \S$ & ND & ND \\
\hline 2 & 8.3 & W & + & 1 & 6.82 & $0.21 末$ & 0.47 & 0.25 & 7.70 & 0.59 & 1.71 \\
\hline 3 & 3.3 & W & + & 4 & 6.66 & $0.30 \ddagger$ & 0.54 & 0.39 & 8.24 & 0.62 & 2.10 \\
\hline 4 & 14.1 & W/AI & + & 2 & 4.14 & $0.61 \%$ & 0.21 & 0.20 & 6.86 & 1.00 & 1.41 \\
\hline 5 & 2.9 & W & - & 1 & 9.72 & $0.26+$ & 0.39 & 0.09 & 10.20 & 1.33 & 2.40 \\
\hline 6 & 4.1 & W & - & 3 & 2.681 & $0.34 \ddagger$ & 0.12 & 0.01 & 5.12 & 0.52 & 0.66 \\
\hline 7 & 1.3 & $\mathrm{~B}$ & - & 2 & ND & $0.22 \neq$ & ND & ND & $3.06 \div$ & $<0.40 \|$ & 0.45 \\
\hline 8 & 0.9 & W & + & 0 & ND & $0.12 \ddagger$ & ND & ND & ND & ND & ND \\
\hline 9 & 9.5 & W & - & 0 & 5.08 & $0.55 \ddagger$ & 0.25 & 0.18 & 9.85 & 1.07 & 0.80 \\
\hline 10 & 7.3 & B & ND & 0 & 5.07 & $0.46+$ & 0.39 & 0.34 & ND & ND & ND \\
\hline 11 & 6.3 & W & - & NCI & 6.73 & $0.42 \ddagger$ & 0.14 & 0.63 & 9.68 & 1.45 & 1.16 \\
\hline
\end{tabular}

*B, Black; W, Caucasian; AI, American Indian.

$+V$ isits to the physician for infection during the 12 mo before the initial blood sample.

$\ddagger$ Value low for age.

$\S$ Not done because of insufficient quantity of serum.

IInsufficient sample to repeat at lower dilution.

I Unable to contact patient to obtain detailed clinical information. 
Table 3. Follow-up immunologic and clinical features

\begin{tabular}{|c|c|c|c|c|c|c|c|c|c|c|c|c|c|c|c|}
\hline \multirow[b]{3}{*}{ Subject } & \multirow{3}{*}{$\begin{array}{c}\text { Interval } \\
(y)^{*}\end{array}$} & \multirow[b]{3}{*}{ Age $(y)$} & \multirow[b]{3}{*}{ Visit/(y)† } & \multicolumn{7}{|c|}{ Ig concentration $(\mathrm{mg} / \mathrm{mL})$} & \multicolumn{5}{|c|}{ Antibody to Hib PS $(\mu \mathrm{g} / \mathrm{mL})$} \\
\hline & & & & \multirow[b]{2}{*}{$\mathrm{G}_{1}$} & \multirow[b]{2}{*}{$\mathrm{G}_{2}$} & \multirow[b]{2}{*}{$\mathrm{G}_{3}$} & \multirow[b]{2}{*}{$\mathrm{G}_{4}$} & \multirow[b]{2}{*}{$\mathrm{G}$} & \multirow[b]{2}{*}{ A } & \multirow[b]{2}{*}{$\mathrm{M}$} & \multirow{2}{*}{$\begin{array}{l}\text { Age }(y) \ddagger \\
\text { Vaccine }\end{array}$} & \multicolumn{2}{|c|}{ Total } & \multirow[b]{2}{*}{$\operatorname{lgG}_{1}$} & \multirow[b]{2}{*}{$\mathrm{IgG}_{2}$} \\
\hline & & & & & & & & & & & & Pre & Post & & \\
\hline 1 & 2.6 & 7.2 & 0 & 8.65 & 1.69 & 0.29 & 0.21 & 11.20 & 1.56 & 1.30 & 4.4 & NDß & 6.3 & $<0.5$ & $<0.3$ \\
\hline 2 & 5.1 & 13.4 & 0 & 6.44 & 2.39 & 0.57 & 0.12 & 13.00 & 0.84 & 3.60 & $13.4 \|$ & $1.2 \|$ & ND & $<0.5$ & 0.6 \\
\hline 3 & 1.6 & 4.9 & 2 & 7.97 & 0.38 I & 0.48 & 0.24 & 7.51 & 0.70 & 1.98 & 3.0 & ND & 17.5 & 4.4 & 0.7 \\
\hline 4 & 1.5 & 15.6 & 1 & 4.01 & $1.07 \pi$ & 0.26 & 0.33 & $5.23^{* *}$ & 0.99 & 1.07 & 15.8 & 0.9 & $35.0 \dagger \dagger$ & 6.7 & 2.3 \\
\hline 5 & 1.6 & 4.5 & 0 & 8.43 & $0.22^{* *}$ & 0.28 & 0.08 & 9.57 & 0.81 & 1.78 & 4.8 & 0.2 & 80.0 & 16.8 & 2.7 \\
\hline 6 & 2.5 & 6.6 & 3 & 5.58 & $0.37^{* *}$ & 0.23 & 0.03 & 8.58 & 1.40 & 0.80 & 4.1 & ND & 7.5 & 3.7 & $<0.3$ \\
\hline 7 & 1.0 & 2.3 & 1 & 3.51 & $0.34^{* *}$ & 0.34 & 0.70 & 4.77 & 0.41 & $0.41^{* *}$ & 2.0 & 0.1 & $0.1^{* *}$ & $<0.5$ & $<0.3$ \\
\hline 8 & 1.9 & 2.8 & 3 & 6.92 & $0.37^{* *}$ & 0.43 & 0.10 & 9.06 & 0.55 & 1.09 & 2.4 & ND & 0.8 & $<0.5$ & $<0.3$ \\
\hline 9 & 2.5 & 12.0 & 3 & 6.61 & $0.83^{* *}$ & 0.28 & 0.29 & 9.45 & 1.25 & 0.64 & $2.5 \|$ & $0.7 \|$ & ND & $<0.5$ & $<0.3$ \\
\hline
\end{tabular}

* Interval between initial serum sample and follow-up.

+ Visits to the physician for infection during the 12 mo before obtaining the follow-up blood sample.

$\ddagger$ Subjects $1,3,5,6,7,8$ had subnormal serum concentrations of $\operatorname{IgG} 2$ when immunized; subject 4 had a low-normal serum IgG2 concentration.

$\S$ Not done because of insufficient quantity of serum, or vaccine not given.

II Vaccine not given.

I Value near lower limit of the normal bounds.

** Value low for age.

† Hib PS-D vaccine given.

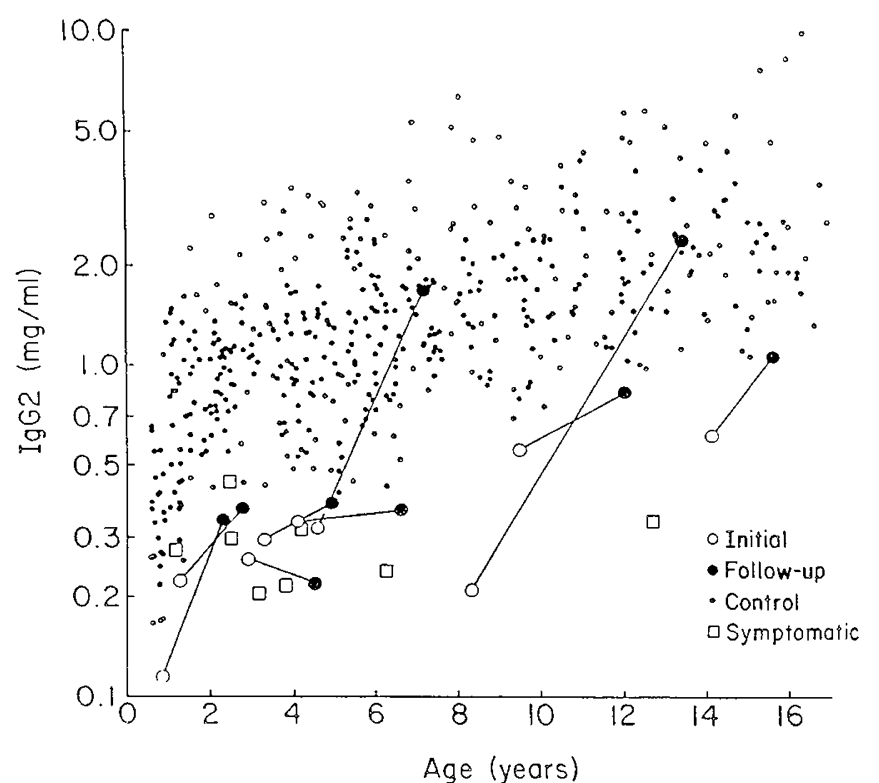

Fig. 1. Initial and follow-up serum IgG2 concentrations of apparently healthy children with low serum IgG2. Values for 483 controls with serum $\mathrm{IgG} 2$ in the normal range are shown. For comparison, values of serum IgG2 in eight infection-prone children with low serum concentrations of IgG2 and antibody deficiency are shown.

serum antibody response to immunization (Fig. 2). This child also had persistently subnormal concentrations of serum IgG2, low-normal serum IgG, subnormal serum IgM, and a decreased percentage of B cells in peripheral mononuclear cells (see below). Subject 7 was subsequently immunized with one dose of $\mathrm{Hib}$ PS-D conjugate vaccine and developed $2.8 \mu \mathrm{g} / \mathrm{mL}$ of total antiHib PS antibody in serum obtained 1 mo later. However, there was no measurable $\operatorname{IgG} 1$ or $\operatorname{IgG} 2$ component in this response as determined by ELISA.

Lymphocyte studies. Lymphocyte populations and in vitro secretion of Ig by mitogen-stimulated PBL were measured in seven of the nine children, six of whom had persistently subnormal or low-normal serum IgG2 (Table 4). For each assay, two age-matched control children with normal serum IgG2 concentrations were tested concurrently. All seven children tested had

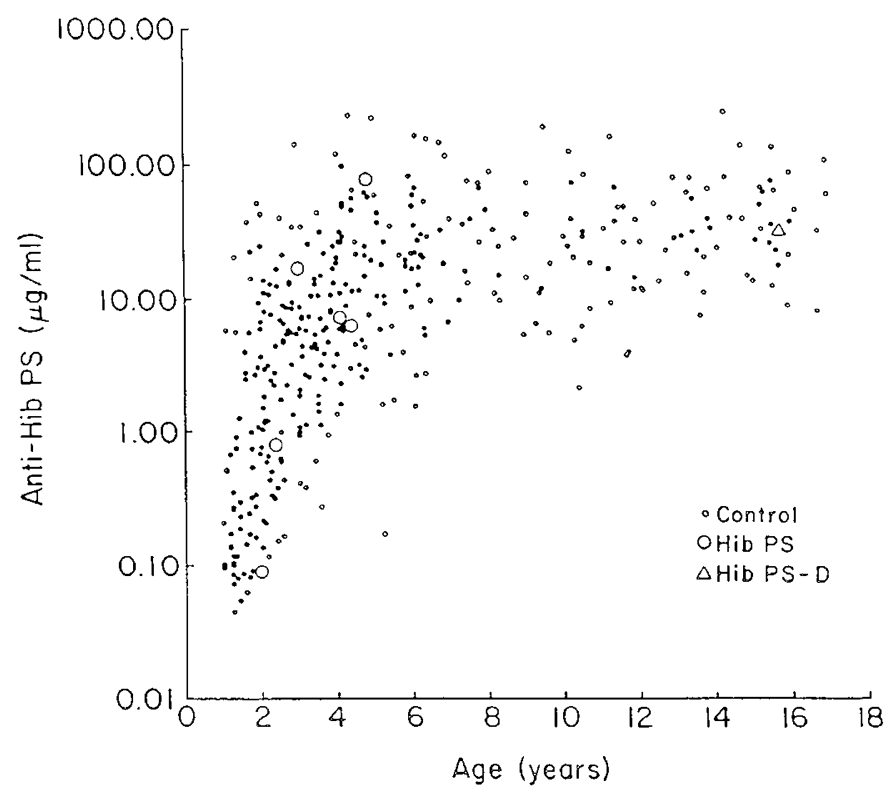

Fig. 2. Total anti-Hib PS antibody concentrations in serum obtained 1 to 2 mo after immunization with Hib PS vaccine in 386 healthy controls 18 mo to 17 y of age and six children with low serum $\operatorname{IgG} 2$. One subject with low serum IgG2 was immunized with Hib PS-D conjugate vaccine.

normal distributions of $\mathrm{T}$ lymphocyte subpopulations (data not shown). Two children had normal secretion of $\operatorname{IgG} 1$, IgG2, and IgG3: subject 1, whose serum IgG2 concentration had increased to normal (Table 3) and, of note, subject 7 who had a subnormal percentage of $B$ cells (Table 4), persistently subnormal serum $\mathrm{IgG} 2$ concentrations, and a poor response to $\mathrm{Hib}$ PS vaccine (Table 3). The other five children, all of whom had subnormal or low-normal serum IgG2 concentrations, showed decreased secretion of $\operatorname{IgG} 2$, and two of the five also had decreased secretion of IgG1 and IgG3 (Table 4).

\section{DISCUSSION}

The recent availability of assays to measure accurately human IgG subclasses, and the development of Ig preparations that can 
Table 4. In vitro secretion of Ig by mitogen-stimulated B cells

\begin{tabular}{cccccc}
\hline & & \multicolumn{2}{c}{$\mathrm{Ig}\left(\mathrm{ng} / \mathrm{mL} / 8 \times 10^{5}\right.$ cells } & \\
\cline { 3 - 5 } Subject & Age(y) & $\mathrm{IgG}_{1}$ & $\mathrm{IgG}_{2}$ & $\mathrm{IgG}_{3}$ & \%B cells* \\
\hline 1 & 7 & 10805 & 454 & 312 & 12.4 \\
3 & 5 & $\mathrm{ND} \dagger$ & $16 \ddagger$ & $\mathrm{ND}$ & 15.5 \\
4 & 16 & $2735 \ddagger$ & $175 \ddagger$ & $323 \ddagger$ & 8.2 \\
5 & 5 & 15070 & $38 \ddagger$ & 497 & 12.3 \\
6 & 7 & 5638 & $52 \ddagger$ & 287 & 8.6 \\
7 & 2 & 5478 & 179 & 249 & $3.6 \ddagger$ \\
8 & 3 & $2462 \ddagger$ & $37 \ddagger$ & $123 \ddagger$ & 8.6
\end{tabular}

Controls (range)

$n=7 \quad 10$-adult $\quad 6646-17408 \quad 357-3050 \quad 500-1698 \quad 4.5-11.9$

$\begin{array}{llllll}n=10 & 2-9 & 4200-42000 & 120-510 & 210-900 & 6.1-14.7\end{array}$

* Enumeration of leukocyte populations performed on isolated mononuclear cells.

$\dagger$ Not done because of technically unsatisfactory assay.

$\ddagger$ Below normal range.

safely be administered intravenously, have heightened the interest of clinicians in the clinical syndromes referred to as "selective IgG subclass deficiencies." Our studies of 11 apparently healthy children, selected on the basis of serum IgG2 concentrations $>2$ SD less than the mean for age, showed that subnormal serum IgG2 does not necessarily reflect a functional immunodeficiency. By careful history and clinical follow-up, only one child had any evidence of increased susceptibility to infection and, in that child, the serious infections had occurred 9 y before study. These observations are noteworthy considering the fact that the low serum IgG2 concentrations of some of these children were in a range observed in infection-prone children with $\mathrm{IgG} 2$ subclass deficiency associated with antibody deficiency (Fig. 1). Further, the clinical histories of the infection-prone children differed strikingly from the histories of the subjects in this study. Most of the infection-prone children had recurrent sinusitis and/or pneumonia requiring visits to their physicians every 4 to $6 \mathrm{wk}$; one child had four bacteremic $H$. influenzae type b infections. In the present study, we could not attribute the subnormal serum IgG2 concentrations in the asymptomatic children to variation of regulation of total serum IgG2 concentration by genes linked with the $\mathrm{G} 2 \mathrm{~m}(23)$ locus because only four of the eight Caucasian children tested were $\mathrm{G} 2 \mathrm{~m}(23)$ negative, a frequency not significantly different from that expected in the general population (17, 22).

On follow-up immunologic evaluation of nine of the 11 children, two experienced increases of $\mathrm{IgG} 2$ to the normal range, and seven had persistently subnormal or low-normal IgG2. The two who developed normal IgG2 concentrations had no other immunologic abnormalities and probably represent a benign variant of transient hypogammaglobulinemia of infancy. Of the seven children with persistently subnormal or low-normal serum IgG2 concentrations, five had normal levels of all other Ig, and four of five tested had normal quantitative and qualitative antibody responses to conventional Hib PS vaccine. Subject 9, who had not been immunized, had a total anti-Hib PS of $0.7 \mu \mathrm{g} / \mathrm{mL}$ that would be in the high normal range for an unimmunized child of 2.5 y (14). Subject 4 , who inadvertently received Hib PS-D conjugate instead of Hib PS, showed high total and IgG antibody responses. These results are in marked contrast to those of infection-prone children with persistently subnormal or lownormal serum concentrations of IgG2 (25a). The latter consistently had very poor antibody responses to Hib PS, and many also had abnormal levels of other Ig isotypes.

In view of the apparent excellent health of the children in the present study, and their generally normal serum Ig, and normal responses to Hib PS vaccine, we were surprised to find that mitogen-stimulated in vitro production of $\operatorname{IgG} 2$ was decreased in five of seven children studied. Thus, this in vitro finding suggests that the low serum concentration of $\mathrm{IgG} 2$ in these children may reflect decreased production of IgG2 in response to mitogenic or other nonspecific stimuli occurring in vivo. It should be noted that the in vitro abnormality seen in these children was milder as well as qualitatively different from that seen by us in infectionprone children with subnormal levels of serum IgG2 (25a). Peripheral blood mononuclear cells from infection-prone children produce much lower amounts of $\mathrm{IgG} 2$, and also produce extremely small amounts of IgG1 and IgG3. In contrast, PBL from the children in our study produced $\mathrm{IgG} 2$ only slightly less than normal and, in most children, their abnormality was limited to $\operatorname{IgG} 2$.

Patients deficient in terminal complement components experience sporadic but severe meningococcal infections $(26,27)$. Also, despite apparent health in most IgA-deficient patients, there is an increased incidence of autoimmune disease among IgAdeficient individuals $(28,29)$. Thus, we plan to follow the clinical status of these apparently healthy children with subnormal IgG2 levels over a longer period of time.

Finally, an important implication of this study is that a subnormal concentration of serum $\operatorname{lgG} 2$ does not necessarily reflect a deficiency in specific antibody responses, and is not a sufficient explanation for increased susceptibility to infection. Children with subnormal serum concentrations of $\operatorname{IgG} 2$ should not be treated with intravenous Ig without further evaluation, particularly a careful clinical assessment and demonstration of abnormal specific antibody responses.

Acknowledgments. Drs. Richard Lazaroff, Patricia Wolff, Janet Ruzycki, Susan Nelson, Eyla Boies, Jill Baer, and Miriam Behar collected the sera from healthy children. Dr. Paul Granoff, Kathy Sheetz, R.N., and Karen Schooley, R.N., vaccinated control subjects and collected sera. Anthony Quinn, Venita Boelloeni, Kim Macke, and Chris Sunwoo provided excellent technical assistance. Gary Elliot performed cytometry. Sharon Bader performed the $\mathrm{IgG}, \mathrm{IgA}$, and $\operatorname{IgM}$ assays. Darlene Bradley typed the manuscript. Drs. Geoffrey Weinberg and Harvey Colten reviewed the manuscript.

\section{REFERENCES}

1. Yount WJ, Dorner MM, Kunkel, HG, Kabat EA 1968 Studies on human antibodies. VI. Selected variations in subgroup composition and genetic markers. J Exp Med 127:633-646.

2. Scott MG, Shackelford PG, Briles DE, Nahm MH 1988 Human IgG subclasses and their relation to carbohydrate antigen immunocompetence. Diag Clin Immunol 5:241-248.

3. Van Der Giessen M, Rossouw E, Algra-VanVeen T, Van Loghem E, Zegers BJM, Sander PC 1975 Quantitation of IgG subclasses in sera of normal adults and healthy children between 4 and 12 y of age. Clin Exp Immunol 21:501-509

4. Schur PH, Rosen F, Norman ME 1979 Immunoglobulin subclasses in normal children. Pediatr Res 13:181-183.

5. Shackelford PG, Granoff DM, Nahm MH, Scott MG, Suarez B, Nelson SJ 1985 Correlation of serum immunoglobulin subclass concentrations with antibody response of children to immunization with Haemophilus influenzae type b polysaccharide-pertussis vaccine. J Clin Immunol 5:390-395.

6. Schur PH, Borel H, Gelfand EW, Alper CA, Rosen FS 1970 Selective gammaglobulin deficiencies in patients with recurrent pyogenic infections. $\mathrm{N}$ Engl J Med 283:631-634.

7. Oxelius VA, Laurell AB, Lindquist B, Golebiowska H, Axelsson U, Björkander J, Hanson LA 1981 IgG subclasses in selective IgA deficiency. Importance of IgG2 -IgA deficiency. N Engl J Med 304:1476-1477.

8 Umetsu DT, Ambrosino DM, Quiati I, Siber GR, Geha RS 1985 Recurrent sinopulmonary infection and impaired antibody response to bacterial capsular polysaccharide antigen in children with selective IgG-subclass deficiency. N Engl J Med 313:1247-1251.

9. Shackelford PG, Polmar SH, Mayus JL, Johnson WL, Corry JM, Nahm MH 1986 Spectrum of $\mathrm{IgG2}$ subclass deficiency in children with recurrent infections: prospective study. J Pediatr 108:647-653.

10. Oxelius VA 1974 Chronic infections in a family with hereditary deficiency of IgG2 and IgG4. Clin Exp Immunol 17:19-27.

11. Söderström T, Söderström R, Andersson R, Lindberg J, Hanson LA 1988 Factors influencing IgG subclass levels in serum and mucosal secretions. Monogr Allergy 23:236-243. 
12. Lefranc M, Lefranc G, Rabbitts TH 1982 Inherited deletion of immunoglobulin heavy chain constant region genes in normal human individuals. Nature 300:760-762.

13. Migone N, Olivero S, Delange G, Delacroix DL, Boschis D, Altruda F, Silengo L, DeMarchi M, Cabonara AO 1984 Multiple gene deletions within the human immunoglobulin heavy chain cluster. Proc Natl Acad Sci 81:58115815 .

14. Granoff DM, Munson, RS Jr 1986 Prospects for prevention of Haemophilus influenzae type b disease by immunization J Infect Dis 153:448-458.

15. Madassery JV, Kwon OH, Lee SY, Nahm MH 1988 IgG2 sublcass deficiency: IgG subclass assays and IgG2 concentrations among 8015 blood donors. Clin Chem 34:1407-1413.

16. Scott MG, Nahm MH 1984 Mitogen induced human IgG subclass expression. J Immunol 133:2454-2460.

17. Granoff DM, Shackelford PG, Pandey JP, Boies EG 1986 Antibody responses to Haemophilus influenzae type b polysaccharide vaccine in relation to the $\mathrm{Km}(1)$ and G2m(23) immunoglobulin allotypes. J Infect Dis 154:257-264.

18. Mäkelä O, Mattila P, Rautonen N, Seppälä I, Eskola J, Kayhty H 1987 Isotype concentrations of human antibodies to Haemophilus influenzae type b polysaccharide in young adults immunized with the polysaccharide as such or conjugated to a protein. J Immunol 139:1999-2004.

19. Shackelford PG, Granoff DM, Nelson SJ, Scott MG, Smith DH, Nahm MN 1987 Subclass distribution of human antibodies to Haemophilus influenzae type b capsular polysaccharide. J Immunol 138:587-592.

20. Fyfe G, Cebra-Thomas JA, Mustain E, Davie JM, Alley CD, Nahm MH 1987 Subpopulations of B lymphocytes in germinal centers. J Immunol 139:21872194.

21. Grubb R 1970 The genetic markers of immunoglobulins. In: Kleinzeller A Springer GF, Wittmann HG (eds) Molecular Biology Biochemistry and
Biophysics, Vol 9. Springer Verlag, New York, pp 109-110

22. Shackelford PG, Granoff DM, Nahm MN, Scott MG, Suarez B, Pandey JP, Nelson SJ 1985 Relation of age, race, and allotype to immunoglobulin subclass concentrations. Pediatr Res 19: 864-849.

23. Morell A, Skvaril F, Steinberg AG, VanLoghem E, Terry WD 1972 Correlation between the concentrations of the four subclasses of $\mathrm{IgG}$ and $\mathrm{Gm}$ allotypes in normal human sera. J Immunol 108:195-206.

24. Gordon LK 1984 Characterization of a hapten-carrier conjugate vaccine Haemophilus influenzae-diphtheria conjugate vaccine. In: Chanock RM, Lerner RA (eds) Modern Approaches to Vaccines. Cold Spring Harbor Press, Cold Spring Harbor, NY, pp 393-396.

25. Granoff DM, Weinberg GA, Shackelford PG 1988 IgG subclass response to immunization with Haemophilus influenzae type b polysaccharide-outer membrane protein conjugate vaccine. Pediatr Res 24:180-185.

25a. Shackelford PG, Granoff DM, Polmar SH, Scott MG, Goskowicz MC, Madassery JV, Nahm MH Subnormal serum concentrations of $\mathrm{IgG}_{2}$ in children with frequent infections associated with varied patterns of immunologic dysfunction. J Pediatr (in press)

26. Ross SC, Densen P 1984 Complement deficiency states and infection epidemiology, pathogenesis, and consequences of neisserial and other infections in an immune deficiency. Medicine 63:243-273.

27. Leggiadro RF, Winkelstein JA 1987 Prevalence of complement deficiencies in children with systemic meningococcal infections. Pediatr Infect Dis 6:7576.

28. Ammann AJ, Hong R 1971 Selective IgA deficiency: presentation of 30 cases and a review of the literature. Medicine 50:223-236.

29. Hayakawa H, Iwata T, Yata J, Kobayashi N 1981 Primary immunodeficiency syndrome in Japan. I. Overview of a nationwide survey on primary immunodeficiency syndrome. J Clin Immunol 1:31-39. 